\title{
The concealment of bodies during the military dictatorship in Uruguay $(1973-84)^{1}$
}

\author{
José López Mazz
}

The political violence that occurred in Latin America during the second half of the twentieth century was deeply rooted in historic and prehistoric cultural traditions. To study it in a scientific way accordingly requires both the development of a specific set of cultural and historical methodologies and a leading role to be played by archaeological techniques and forensic anthropology.

Our focus is in part on apprehending and understanding violent practices occurring within social and political systems. Furthermore, we are also concerned with developing strategies and (field and laboratory) instruments that allow us to identify the different contexts and settings of this violence. This is a vital task for certain recent historical periods, such as the Southern Cone dictatorships, where there existed the desire to hide and mask political violence and the disappearing of opponents, as well as systematic practices designed to achieve this end.

Although the dictatorship lasted from 1973 until 1984, violent political practices paved the way for it from the mid-1960s. During that period there was an increase in conflicts over land ownership (sugar-cane workers) and over low salaries and civil rights (labour laws). The first instances of disappeared and murdered political detainees occurred in the early 1970s. Shortly afterwards the armed conflict with Tupamaro guerrillas and the coup itself accentuated the level of violence, which was part of a well-defined political strategy and the overall system of social control. ${ }^{2}$ 
This study focuses on the complicated problems involved in the identification of corpses, concealed in different ways across different scenarios during this violent period. In this context overcoming the challenges of the identification process became important for understanding the practices employed by the police and military in their treatment of the bodies of their political victims, during a period that would come to be referred to as one of 'state terror'. It presents the repertoire of procedures used by the repressors in 'disappearing' the bodies of political victims. It furthermore presents the strategic principles and technical activities deployed by the Grupo de Investigación en Antropología Forense (Forensic Anthropology Research Group; GIAF) of Uruguay's public university (UdelaR) in its search for and discovery of, and the examination and identification of, the bodies of disappeared detainees.

Of particular interest here is a discussion of the scientific procedures and the protocol used to ensure family members, judges, and citizens gain greater access to searches that bring a good chance of a discovery being made, a reliable identification, and a proper examination of the causes of death. Adopting scientific methods was consistently found to be the most appropriate way to address the many practical problems of the investigation. This was particularly the case when it came to dealing with misinformation that was often passed on to researchers to mislead their search activities.

The goal was to support the justice system in its cases and investigations by clearly addressing the issues involved and assessing the evidence in each case. We moreover wanted to help with rescuing and developing a social memory, as well as help to find material foundations for hypotheses relating to what is a little-understood period of Uruguay's recent history. It was necessary to design the research around specific case-by-case, problem-by-problem approaches that were capable of producing empirical examples to go with each hypothesis and existing testimony. Until 2005 all accounts and explanations of the fate of disappeared detainees remained speculative and were beyond the scope of any strategy to verify them.

\section{The roots of political violence in the River Plate region}

To understand the atrocities of the Uruguayan dictatorship (1973-84) one must take into account its different antecedents, which contributed to the political violence that took place in the River Plate region 
in the second half of the twentieth century and further developed its particular characteristics. Violent social practices in this region have an ancient cultural significance, and they brought their own rhythm to the area's long-term historical processes.

Acts of genocide, mass graves, clandestine grave sites, and the destruction of bodies form part of a strategy that we know from archaeological and ethnographic research has existed in this region since the first millennium BC. ${ }^{3} \mathrm{~A}$ full repertoire of violent pre-Columbian practices that included scalping, displaying severed heads (as trophies), cannibalism, and the dismemberment of bodies has been recorded in research from the field of prehistory ${ }^{4}$ and from ethnographic studies of the eighteenth through to the twentieth century. ${ }^{5}$

Significant levels of violence and social conflict emerged among the pre- and proto-historic peoples living in the lowlands of eastern Uruguay, western Argentina, and southern Brazil in tandem with new economic structures that were linked to population growth, a move towards a sedentary lifestyle, and more territorial behaviour. ${ }^{6}$

Furthermore, peoples from Amazonia (the Arawak and Guarani) began arriving in the region from the first millennium BC, creating conflict with and resistance from local populations (the Timbus, the Charrúa, and the Minuane). When the first Spaniards and Portuguese arrived in the region in the sixteenth century they noted a conflict between the peoples inhabiting the coast and those who not long before had been forced inland.?

In 1686 the Indian Lorenzo Tiembla Tierra (Lorenzo EarthShaker), who led a revolt against the Spaniards of the village of Santo Domingo de Soriano, was tried and executed in a way intended to serve as an example to others. ${ }^{8}$ His body was dismembered and his head, arms, legs, and torso were displayed at the different routes that led to the city of Buenos Aires. ${ }^{9}$ During the war with Paraguay in the second half of the nineteenth century thousands of African slaves were sent to front-line battalions. The Balkanization of the Spanish colonies that gave rise to the new nation-states of Argentina, Uruguay, and Paraguay was also a period of very violent civil wars, with ears and heads cut off, throats slit, as well as torture and mass executions. ${ }^{10}$

The main socio-historical contradiction of not just the Spanish and Portuguese colonies of the seventeenth, eighteenth, and nineteenth centuries but also of the nineteenth-century independence processes was identified by creole intellectuals of this region of South America as a dialectic crisis 'between savagery and barbarism. ${ }^{11}$ Indigenous, African and, creole (gaucho) forms of resistance were 
criminalized as illegitimate behaviour that was above all a product of the primitiveness of indigenous and African life.

For centuries there was a profound social crisis involving economic and political tensions that were strongly linked to the 'colonial order'. The colonial order was also characterized by daily political and social violence against Indians and African slaves. It was controlled by colonial institutions and the Catholic Church. Authoritarian and deterrent practices provoked a strong reaction from creoles who sought independence. The civilizing role of Christian religion and morality and the heavy hand of the conquerors were the key tools for making the savages of South America 'submit' to the Faith. ${ }^{12}$

Both interpersonal and collective violent practices are part of contemporary South America's oral tradition and collective imagination. The arrival of immigrants and the birth of the first labour unions in the early twentieth century led to new conflicts and the police disappearing some anarchists. ${ }^{13}$

Another more recent but critically important antecedent for understanding violence in this region was the foreign policy of the United States in Latin America, which considered the region to be its 'backyard'. During the twentieth century the United States developed a geopolitical approach based on an interest in the strategic value of certain places (Panama) and, above all, of a wide range of natural resources. During the Cold War and following the Cuban Revolution this process was accompanied by a military presence on the ground, and often the training of army officers and local police forces.

Larger numbers of American security consultants arrived during this era, in particular to help the government with confronting guerrilla forces. This cooperation resulted in the Uruguayan police developing specialisms and technical expertise in interrogating political prisoners. ${ }^{14}$ It was also responsible for the emergence of a Death Squad that was supported by the CIA, as well as the beginnings of disappeared detainees, some years before the 1973 coup. ${ }^{15}$ The Uruguayan police's usual, 'manual' application of torture was replaced by procedures involving the application of electrical instruments such as the famous 'prod', which were intended to deliver better results and inflict fewer marks, both on the bodies of political detainees and on public opinion. ${ }^{16}$ The contemporary chapter of mass political violence begins with the events of 1968 and definitively comes to the fore in 1973, with coups in the region (Brazil in 1964, Argentina in 1964 and 1975, Chile in 1973, and Uruguay in 1973) consolidating army hegemony over the forces of repression. This change also created a new territorial scope for 'state terrorism', an extension of 
the population at which it was directed, and the setting up of a new logistical structure for it. All this would lead to an increase in the number of people who were tortured and killed. Soldiers trained by the United States in its military's School of the Americas, located in Panama, would learn counter-revolution and counter-information techniques. ${ }^{17}$ They would also develop personal ties with other soldiers from neighbouring countries (Argentina, Brazil, Paraguay, and Chile), thus making it easier to implement regional coordination of repression. These supranational repressive mechanisms, which included a range of criminal activities that reached across the entire Southern Cone, would become known as Operation Condor.

\section{Mass murder's pressing problem: the fate of the bodies}

Over the course of the period of political repression and dictatorship, the treatment of victims' bodies followed different procedures. It must firstly be said that many of the disappeared political detainees were subject to harsh and systematic torture following their arrival in clandestine prisons. Systematic torture had begun some years earlier, resulting in guerrillas attacking and killing police officers and soldiers belonging to the Death Squad in $1972 .{ }^{18}$ Systematic torture ordered by the military (and the guerrillas' violent response to it) caused political violence to spiral.

The first method used by the military dictatorship to manage corpses was returning the bodies to families while forbidding them to open the coffins to see them. This method was used between 1973 and 1974. In some cases families opened coffins and got a second expert forensic opinion. ${ }^{19}$ This method was abandoned shortly after the coup. It was in this period that the systematic disappearing of political detainees began. The first disappeared detainees were opponents who were accused of being members of guerrilla groups, academics, trade unionists, or members of the communist parties.

As in Argentina, in Uruguay bodies were thrown into the sea and lakes. This included some bodies being thrown into the water along with stones and weights to prevent them resurfacing. In $1974 \mathrm{doz}-$ ens of bodies thrown overboard by the Argentine air force began to reach the Uruguayan coast. It became a public issue, and the military authorities announced that they were the bodies of 'Oriental' sailors killed at sea. In central Uruguay, a body that had been cast into the Rincón del Bonete Lake also surfaced and was found. ${ }^{20}$ 
Between 1974 and 1981 political prisoners were 'transferred' and loaded onto military aircraft that had no destination at the Curbelo airbase (Maldonado) and Carrasco Airbase No. 1 (Montevideo). ${ }^{21}$

Between 1971 and 1974 bodies were left - or rather left out in the open - in the street. Leaving out savagely tortured and murdered bodies served as a deterrent and was a message to the enemy. This method was the first used by the Death Squad (which was made up of policemen, soldiers, and far-right civilians). In 1975, in response to the execution of the Uruguayan military attaché in France, seven bodies of Uruguayan disappeared detainees in Argentina were left, displaying signs of torture, in a small town close to Montevideo. ${ }^{22}$

The different methods of treating the bodies of the disappeared detainees each had a deliberate communicative effect and a semiology linked to the circumstances and events of each point in the conflict.

As a result of dozens of bodies of disappeared detainees from 'death flights' washing up on Uruguayan beaches in 1974, the dictatorship was forced to deal with dozens of bodies that had resisted being definitively disappeared. This situation led to a new form of concealment: anonymously depositing bodies in cemeteries under the classic label of 'unidentified'. This method was used both on bodies coming from the sea and also for others that had been subjected to different acts of violence. This episode of bodies of disappeared detainees failing to completely disappear reached the beaches of the River Plate region between Colonia and Montevideo and Maldonado. ${ }^{23}$ Bodies were also recovered from the Atlantic Ocean between Punta del Este and the Brazilian border (Garzón, Rocha, Castillos, Cabo Polonio, Los Moros, and La Coronilla). ${ }^{24}$

As political repression became established in barracks, the most widespread method of concealing bodies began: that of burying bodies under military installations. In various barracks, though particularly in Battalion No. 13 (Instrucciones/Montevideo) and Battalion No. 14 (Toledo/Canelones) different places began to be set up where disappeared-detainee bodies were clandestinely gathered and began to accumulate. ${ }^{25}$ In the paratrooper Battalion No. 14 this activity resulted in a clandestine military cemetery that soldiers called 'Arlington', apparently after the national cemetery in Arlington, Virginia. The bodies of detainees killed under different circumstances started to be taken to this location.

In 1983 (and until 1985) at the same time that democracy returned, and as a result of agreements between military figures and politicians, ${ }^{26}$ the military began to look for bodies that had been 
clandestinely buried with the intention of exhuming them. ${ }^{27}$ This process, known as Operation Carrot, was extended with different outcomes to various burial sites. The process was an organized one, involving planning and the use of machinery, as well as the participation of the military, which some years before had committed the crimes.

The aim of the operation was to make any skeletal remains permanently disappear. To this end the Engineers Battalion carried out the job, either by hand or with machines. ${ }^{28}$ According to the reports that the military handed over to the Presidency of the Republic and the Peace Commission in 2004, all bodies appeared to have been burned and the remains thrown into the Bay of Montevideo. ${ }^{29}$ However, the excavation works carried out by the GIAF managed to locate some bodies that the military had reported as destroyed during the operation. ${ }^{30}$

The archaeological work carried out by the GIAF succeeded in locating several material traces of Operation Carrot, whose explanation for the fate of the human remains had been fiercely contested by the families of disappeared detainees. Two new elements come into play from 2005. Firstly, studies of aerial photography show various renovation activities on existing buildings in these places. ${ }^{31}$ Furthermore, new information from former military figures indicated that bodies recovered during Operation Carrot could have been reburied under different military buildings. Consequently, with bodies having been recovered and reburied shortly afterwards, this provisional typology came to an end for the time being. This provisional typology is interesting from both a criminological and chronological standpoint. Studying the treatment of the bodies of disappeared detainees has a methodological value in studying the conflict and helps researchers better understand the history and circumstances of the repression that took place.

\section{Research challenges and the concealment of bodies}

The systematic concealment of bodies had different aims, depending on the period of political repression. On the one hand, the practice repudiated the plan to exterminate enemies of the regime. At the same time, it prevented traces from being found and impeded the workings of the justice system. On the other hand, the physical disappearing of citizens was part of an overall strategy of long-term terror. 
The disappearing of opponents was gradually phased in, but came about especially with the development and implementation of Operation Condor and the increasing concern of international public opinion over human-rights violations in Uruguay. Indeed, the United Nations was aware of what was going on and demanded specific answers from the military government. ${ }^{32}$

The search for the bodies of disappeared detainees has represented until now a complex and long-standing problem. Its challenges have required the input of more specific disciplinary fields such as archaeology and forensic anthropology. Archaeology has allowed the pursuit of searching for and finding bodies on the back of very fragmented (and sometimes false) information. It has also been a technical challenge to carry out searches over large tracts of land where it seemed probable discoveries would be made.

At the same time, technical developments in archaeological excavations made it possible to reconstruct crime scenes and identify some of the 'patterns' of criminal behaviour. Forensic anthropology has for its part allowed the torture - and in several cases, the causes of death - of bodies to be known and understood. There were clear patterns of peri-mortem fractures to the bones of the victims (to the ribs, legs, arms, and skulls), allowing inferences and theories about the conditions endured by disappeared detainees during their clandestine confinement to be made. ${ }^{33}$

DNA identification has brought one of the greatest scientific and legal developments by allowing bodies to be identified without the ambiguity of other commonly used methods such as 'facial reconstruction. Misidentifications carried out by specialized judicial forensic services in Uruguay and Chile have created a moral and ethical debate about reliable identification. ${ }^{34}$

Field research conducted by the GIAF has allowed the identification of a succession of operations aimed at concealing bodies under Battalion No. 13 that were carried out systematically. ${ }^{35}$ Burials in pits dug under the barracks that were covered with lime were also concealed with concrete slabs. A training area for tanks was subsequently set up over the bodies, and eventually the whole area was carefully forested. ${ }^{36}$

A large amount of false information was sent to the GIAF team in an attempt to mislead its research, something which amounts to another form of active concealment, this time in the democratic era. ${ }^{37}$ In 2004 the Peace Commission created by President Jorge Batlle heard evidence from military figures which suggested that all of the missing bodies had been exhumed (in Operation Carrot), 
then burned and the ashes thrown into the Bay of Montevideo or disposed of at Battalion No. $14 .^{38}$ This false information also sought to continue concealment of the bodies and discourage any further search activity being demanded by relatives.

The active and systematic concealment of disappeared detainees' bodies that was carried out by the military was the biggest challenge faced by researchers, who were also vulnerable to the opportunism of politicians. The only possible response to active concealment was therefore the development of a research strategy that was moreover systematically and scientifically sound. The fact that the team was made up of university academics gave a guarantee that new information produced would be of a high quality and based on international protocols.

Testimonies were firstly classified based on their proximity to the scenes of the crimes, while priority was given to testimonies from people directly involved in the events under analysis (burials, exhumations, etc.). Throughout the research, getting a solid foundation of information on which to carry out the work was a critical problem. This same problem had led to the failure of President Batlle's Peace Commission.

A comparative study of (1:40,000 scale) aerial photographs from between 1966 and 2005 allowed the evolution of and significant changes to the landscape of military land during different moments of the dictatorship (and after the return to democracy) to be ascertained. ${ }^{39}$ The technical overview this offered allowed us to recognize episodes of concealment (afforestation, building construction, renovations, etc.), as well as some episodes linked to Operation Carrot, such as the felling of trees carried out to facilitate the work of the machinery of the Engineers Battalion. This line of inquiry allowed us to identify the bodies of several disappeared detainees. ${ }^{40}$

The first strategic step was selecting quality witness accounts (direct ones) to allow the identification and delimitation of work areas. The second step was studying the changes and modifications (alterations and renovations) made to the landscape during the period under study. This controlled observation was then followed by archaeological studies aimed at directly surveying and examining large areas. The size of the study areas was different at each battalion and ranged between 1 and 40 hectares, meaning very careful strategic planning was required in the search for human bodies. The final step was to organize a team that was suitable for and capable of pursuing appropriate research over a long period of time. 
In most cases the archaeological excavation technique used was that known as the 'open area or wide area' technique, ${ }^{41}$ which was applied to units of between 1 metre by 2 metres and 10 metres by 10 metres. Applying geophysical 'prospecting' techniques was problematic in some places because of trees and proximity to water.

Systematic excavations facilitated the uncovering of 'primary archaeological contexts' containing material elements that had been present at the crime scenes at the moment atrocities took place. This functional association of objects (clothes, coins, bags, ropes, etc.) and traces of different kinds allowed inferences about the type of atrocity to be made, as well as profiles of their perpetrators. The following different levels of analysis were carried out at the graves of disappeared detainees: (a) the location of the grave site within the battalion; (b) the skeleton and the trauma it had been subjected to; (c) the pit and the techniques and methods used to produce it; and (d) any other associated elements.

The status of scientific evidence needed to be determined on a problem-by-problem basis and in coordination with the judges, prosecutors, and judicial forensic medical examiners. Through these methods, the bodies found, the 'incidents' established through archaeological techniques and the identification of abnormalities found on bones became legal evidence relating to specific instances of violations of human rights.

\section{The archaeological and anthropological reconstruction of 'crimes against humanity'}

Over the twentieth century mass crimes show common logistical challenges that cut across their considerable cultural diversity. For those responsible for repression in Uruguay, concealment came first, making bodies and all evidence disappear, and thus repudiating the crime. The magnitude of the horrors that had been committed highlighted the inability of the military to produce a narrative that could justify the levels of violence. The disappearing, torture, and execution of detainees was to take place outside of any moral or legal system and was to be set up beyond any jurisdictional reach.

The systematic disappearing of opponents was a crime that directly affected key segments of society. The disappearing of bodies, in turn, has an impact on historical memory and human rights. There was no battle, no trial, and no witnesses. No one actually knows what really happened. Procedures initially had to be improvised when the 
dictatorship unleashed its violence. However, the protocols implemented by military bureaucrats eventually standardized and harmonized the military and police procedures and conduct guidelines.

Among the activities that this research was able to verify, there were numerous episodes of concealment and intentional destruction of the bodies of political opponents. This 'dirty war' sought to destroy the evidence of what really happened. There were to be no records nor data to allow a historical reconstruction. However, the combining of archaeological and anthropological techniques allowed firsthand information of a good quality to be found. This information has been of critical importance in not just explaining the violence, but also in developing working hypotheses related to historical and legal problems. Testimony from the soldiers involved is still lacking today. But working hypotheses based on scientific rigour can at least shift research towards new areas. The heuristic value and complementary nature of the different lines of work have created a basis for an interdisciplinary approach. Reciprocity between scientific perspectives can develop a specific epistemology for the study of violence that is more suited to current social needs.

The concealment of bodies occurred at different times during the period of repression, but sometimes it took on a different significance. As we have seen, the first instance of concealment occurred at the moment of a disappeared detainee's death. From 1983 another episode of concealment began. This time it was a specific and specialized operation to ensure (through a supposed pact between politicians and the military) the definitive disappearing of bodies and their remains. All this occurred on the eve of the return to democracy. These were two unique historical moments with two different political objectives, but both had in common a strategy based on disappearing. The first, of a strictly military nature, prioritized the immediate physical disappearance of the enemy. The second prioritized the destruction of historical memory and the possibilities of judicial action against the genocide.

Mass murder occurred in a geographical space in which violence was territorially divided into various specialized areas of activity: secret prisons, places of torture, clandestine graves, and also the ocean (and beaches) into which many bodies were thrown. This cartography also offered a tool through which the itineraries for disappearing bodies could be reconstructed. In this map, the non-places (sensu Augét ${ }^{42}$ are those still-unknown spaces where the remains of disappeared detainees are still concealed. 
Anthropological studies of modern scenarios of this complexity benefit from the contribution of interdisciplinary university teams because they are equal to the challenges of modern science. But academics also understand the social commitments involved in using research as a tool for improving quality of life.

Although in recent years there have been significant advances in the search for bodies, it seems that they are not enough. The final resolution of these socio-historical and political problems still requires input from all those involved in them. Research challenges of the identification process emerge directly from the kind of treatment given to the bodies of missing people by the perpetrator. In Uruguay, concealment and destruction were always the principal challenges for the identification of bodies. Analysed patterns of violence and the identification of corpses are both part of the same research process, which involves historic, genetic, archaeological, anthropological, and forensic approaches.

This very accurate archaeological undertaking in Uruguay has managed to recover some of the remains of bodies buried between 1973 and 1982, later exhumed and destroyed between 1983 and 1985. The great challenge of the identification of bodies is, however, dependent on the scientific protocol to obtain DNA material from an extremely small sample of bones.

\section{Notes}

1 Translation from the author's Spanish by Cadenza Academic Translations.

2 Madres y Familiares de D., A todos Ellos. (Montevideo: Caligráficos. S.A., 2004); V. Martínez, Tiempos de dictadura (Montevideo: Banda Oriental, 2005).

3 J. López Mazz, 'Las estructuras monticulares de las tierras bajas del este de Urugua', Latin American Antiquity, 12:3 (2001), 231-55.

4 J. López Mazz \& F. Moreno, 'El cambio social en la prehistoria de las Tierras Bajas del este de Uruguay: la visibiidad arqueológica del conflicto', in J. López Mazz \& M. Berón (eds), Indicadores arqueológicos de conflicto y violencia (Montevideo: CISC/Udelar, 2013), pp. 19-36.

5 D. Bracco \& J. López Mazz, La insurrección del año 1686 (Montevideo: Linardi y Risso, 2006); P. Clastres, Arqueología de la violencia (Sao Paulo: Brasiliense, 1980).

6 J. López Mazz \& D. Bracco, Minuanes (Montevideo: Linardi y Risso, 2009).

7 P. Lozano, Historia de la conquista del Paraguay, Río de la Plata y Tucumán (Buenos Aires, 1873). 
8 D. Bracco \& J. López Mazz, La insurrección del año 1686 (Montevideo: Linardi y Risso, 2006).

9 Ibid., p. 111.

10 J. Barrán, Apogeo y crisis del Uruguay pastoril y caudillesco (Montevideo: Banda Oriental, 1980).

11 J. López Mazz, 'Approche historique et culturelle à la formation sociale et à l'identité uruguayenne' (doctoral thesis, Université de Lille, 1987).

12 Ibid.

13 V. Martínez, Tiempos de dictadura (Montevideo: Banda Oriental, 2005).

14 A. Rico (ed.), Historia reciente, Montevideo, PNUD/MEC, 2008.

15 E. Fernández Huidobro, La tregua armada (Montevideo: Ediciones Vintén, 1990); Rico, Historia reciente.

16 Fernández Huidobro, La tregua armada.

17 Rico, Historia reciente.

18 Fernández Huidobro, La tregua armada.

19 Madres y Familiares de D., A todos Ellos.

20 Ibid.

21 J. López Mazz (ed.), 'Informe de actividades del Grupo de Investigación en Antropología, FHCE, Presidencia de la República, 2011.

22 A. Rico (ed.), 'Informe final del equipo de historiadores', FHCE/UdelaR, Presidencia de la República, Manuscript, 2012.

23 Ibid.

24 López Mazz, 'Informe de actividades', 2011.

25 Comisión para la Paz, 'Informe final, Presidencia de la República Oriental del Uruguay, 2004; A. Díaz \& E. Barneix, 'Informe del ejército sobre el destino de los detenidos desaparecidos', 'Diario la República', Presidencia de la República Oriental del Uruguay, 2005; Madres y Familiares de D., A todos Ellos.

26 A. Alfonso, Encontrando a los desaparecidos (Montevideo: Caesare, 2006).

27 Comisión para la Paz, 'Informe final'.

28 López Mazz, Informe de actividades, 2011; J. López Mazz (ed.), 'Informe de actividades sobre los trabajos arqueológicos de búsqueda de los detenidos desaparecidos', FHCE, Presidencia de la República, 2012.

29 Comisión para la Paz, 'Informe final'.

30 López Mazz, 'Informe de actividades', 2011; López Mazz, 'Informe de actividades', 2012.

31 Ibid.

32 C. Demasi, A. Marchesi, V. Markarian, A. Rico \& J. Yaffé, La dictadura cívio-militar Uruguay 1973-1985 (Montevideo: Banda Oriental, 2009).

33 López Mazz, 'Informe de actividades', 2012.

34 R. Cáceres, 'Chile, operación retiro de televisores: desaparecer a los desaprecidos', in A. Zarankin, M. Salerno \& M. Perosino (eds), Historias desaparecidas (Córdoba: Encuentro Grupo Editor, 2012), pp. 61-78; J. López Mazz, 'Archaeology of historical conflicts, colonial oppression and political violence', in A. Gonzalez-Ruibal \& G. Moshenka (ed.), Ethics and the Archaeology of Violence (London: Springer, 2015). 
35 J. López Mazz (ed.), 'Informe de actividades del Grupo de Investigación en Antropología Forense’, Presidencia de la República, 2005; López Mazz \& Bracco, Minuanes.

36 López Mazz, 'Informe de actividades', 2005.

37 Ibid.

38 Comisión para la Paz, 'Informe final.'

39 López Mazz, 'Informe de actividades', 2005; López Mazz, 'Informe de actividades', 2011; López Mazz, 'Informe de actividades', 2012.

40 Ibid.

41 E. Harris, Principios de estratigrafía arqueológica (Barcelona: Crítica, 1991).

42 M. Augé, Les non lieux (Paris: Éditions du Seuil, 1992).

\section{Bibliography}

Alfonso, A. Encontrando a los desaparecidos (Montevideo: Caesare, 2006)

Augé, M., Les non lieux (Paris: Éditions du Seuil, 1992)

Barrán, J., Apogeo y crisis del Uruguay pastoril y caudillesco, 3 vols (Montevideo: Banda Oriental, 1980)

Bracco, D. \& J. López Mazz, La insurrección del año 1686 (Montevideo: Linardi y Risso, 2006)

Cáceres, R, 'Chile, operación retiro de televisores: desaparecer a los desaprecido', in A. Zarankin, M. Salerno \& M. Perosino (eds), Historias desaparecidas (Córdoba: Encuentro Grupo Editor, 2012), pp. 61-78

Clastres, P., Arqueología de la violencia (São Paulo: Brasiliense, 1980)

Comisión para la Paz, 'Informe final', Presidencia de la República Oriental del Uruguay, 2004

Demasi, C., A. Marchesi, V. Markarian, A. Rico \& J. Yaffé, La dictadura cíviomilitar Uruguay 1973-1985 (Montevideo: Banda Oriental, 2009)

Díaz, A. \& E. Barneix, 'Informe del ejército sobre el destino de los detenidos desaparecidos, 'Diario la República', Presidencia de la República Oriental del Uruguay, 2005

Fernández Huidobro, E., La tregua armada (Montevideo: Ediciones Vintén, 1990)

Harris, E., Principios de estratigrafía arqueológica (Barcelona: Crítica, 1991)

López Mazz, J., 'Approche historique et culturelle à la formation sociale et à l'identité uruguayenne' (doctoral thesis, Université de Lille, 1987)

López Mazz, J., 'Archaeology of historical conflicts, colonial oppression and political violence, in A. Gonzalez-Ruibal \& G. Moshenka (ed.), Ethics and the Archaeology of Violence (London: Springer, 2015), pp. 71-87

López Mazz, J., 'Las estructuras monticulares de las tierras bajas del este de Uruguay', Latin American Antiquity, 12:3 (2001), 231-55

López Mazz, J., 'Indicadores antropológicos y arqueológicos de violencia política en Uruguay (1973-1984)', in J. López Mazz \& M. Berón (eds), Indicadores arqueológicos de conflicto y violencia (Montevideo: CISC/ Udelar, 2013), pp. 209-22 
López Mazz, J. (ed.), 'Informe de actividades sobre los trabajos arqueológicos de búsqueda de los detenidos desarpeecidos', Facultad de Humanidades y Ciencias de la Educación, IMPO, Presidencia de la República, Uruguay (Montevideo, 2005)

López Mazz, J. (ed.), 'Informe de actividades sobre los trabajos arqueológicos de búsqueda de los detenidos desarpeecidos', Facultad de Humanidades y Ciencias de la Educación, IMPO, Presidencia de la República, Uruguay (Montevideo, 2008)

López Mazz, J. (ed.), 'Informe de actividades sobre los trabajos arqueológicos de búsqueda de los detenidos desarpeecidos', Facultad de Humanidades y Ciencias de la Educación, IMPO, Presidencia de la República, Uruguay (Montevideo, 2011)

López Mazz, J. (ed.), 'Informe de actividades sobre los trabajos arqueológicos de búsqueda de los detenidos desaparecidos', Facultad de Humanidades y Ciencias de la Educación, IMPO, Presidencia de la República, Uruguay (Montevideo, 2012)

López Mazz, J. \& D. Bracco, Minuanes (Montevideo: Linardi y Risso, 2009) López Mazz, J. \& F. Moreno, 'El cambio social en la prehistoria de las Tierras Bajas del este de Uruguay: la visibiidad arqueológica del conflicto', in J. López Mazz \& M. Berón (eds), Indicadores arqueológicos de conflicto y violencia (Montevideo: CISC/Udelar, 2013), pp. 19-36

López Mazz, J. \& M. Berón (eds), Indicadores arqueológicos de conflicto y violencia (Montevideo: CISC/Udelar, 2013)

Lozano, P., Historia de la conquista del Paraguay, Río de la Plata y Tucumán (Buenos Aires, 1873)

Madres y Familiares de D., A todos Ellos (Montevideo: Caligráficos. S.A., 2004)

Martínez, V., Tiempos de dictadura (Montevideo: Banda Oriental, 2005)

Rico, A. (ed.), Historia reciente (Montevideo, PNUD/MEC, 2008)

Rico, A. (ed.), 'Informe final del Equipo de Historiadores', Facultad de Humanidades y Ciencias de la Educación/UdelaR, IMPO/Presidencia de la República, 4 vols (Montevideo, 2005)

Rico, A. (ed.), 'Informe final del Equipo de Historiadores', Facultad de Humanidades y Ciencias de la Educación/UdelaR, Presidencia de la República, unpublished manuscript (2011)

Rico, A. (ed.), 'Informe final del Equipo de Historiadores', Facultad de Humanidades y Ciencias de la Educación/UdelaR, Presidencia de la República, unpublished manuscript (2012) 